$p$-ISSN 1693-9484, $e$-ISSN : 2621-8313

Majalah Ilmiah Bahari Jogja (MIBJ)

Vol. 17 No. 1, Februari 2019 (86-95)

DOI : 10.33489/mibj.v17i1.201

(C) 2019 Akademi Maritim Yogyakarta

BAHARI JOGA

\title{
Globalisasi Transportasi dalam Membuka Peluang Usaha Keagenan yang Didukung oleh Program Tol Laut di Indonesia
}

\author{
Iswanto $^{1^{*}}$, Handoyo Widyanto ${ }^{2}$ \\ ${ }^{1,2}$ Akademi Maritim Yogyakarta, Jl. Magelang KM 4.4, Yogyakarta 55284, Indonesia \\ * Corresponding Author. Email: isnogotirto@yahoo.co.id. Telp.+628122741634
}

\begin{abstract}
Abstrak
Kegiatan pelabuhan yang mempunyai nilai ekonomi tinggi akan menjadi perebutan para pemegang kepentingan, antara Pemerintah sebagai regulator yang dilaksanakan BUMN (bersifat monopoli) dan perusahaan swasta nasional juga ingin mendapatkan bagian kue kegiatan yang tersebut.

Secara ekonomi bahwa satu kegiatan monopoli biasanya kurang sehat dan cenderung diselewengkan kegiatan dimaksud sejak kapal masuk sudah harus berurusan dengan regulator, kapal sandar, bongkar muat dan kapal meninggalkan pelabuhan, sehingga ingin segera dilayani dan segera meninggalkan pelabuhan.

Regulasi yang dilaksanakan pemerintah dengan monopoli menjadi masalah karena urusan fisik kapal, awak namun kegiatan bongkar muat masih ada peran swasta yang juga berkepentingan, dan selama ini masih terpinggirkan.
\end{abstract}

Kata Kunci: Regulasi, monopoli dan aktifitas

Abstract

Port activities with its high economic value will be a strategic target for all stakeholders, between Government as policy regulator trough State-Owned Enterprises which is monopolistic and national private companies which also wants to take benefit from the activities.

Commonly monopolistic activity tend to be distorted for example activities of vessel's arrival, berthing, loading and unloading activities which deal with port regulator/administrator to activities of vessel's departure

Regulation condueted by government using monopolistic way become a problem due to the contribution of private companies as well in the process of ship physical affair, vessel manning loading and unloading which recently left-behind

Keywords: Regulation, Monopolies and Activities

\section{PENDAHULUAN}

Perkembangan dunia yang semakin terbuka/mengglobal membuka banyak peluang di banyak sektor saat ini, sebagaimana di Indonesia hampir setiap gerak/aktivitas yang dilakukan baik langsung maupun tidak langsung akan mendatangkan nilai ekonomi yang sangat tinggi, tergantung usaha apa yang dikelolanya.

Jenis usaha yang dikembangkan mulai dari tingkat yang yang paling rendah (perorangan) sampai usaha besar yang dikelola perusahaan swasta maupun pemerintah sabagai contoh dibidang transportasi dari menggunakan motor didarat sampai Pesawat terbang di udara dan kapal di laut, semuanya mengalami 
peningkatan bahkan saat ini telah didukung oleh infrastruktur dan suprastruktur yang sangat memadahi baik melalui fisik maupun dunia maya.

Pada tulisan ini penulis akan mengelaborasi sebagian dari berbagai usaha tersebut yang titik beratnya yang berhubungan dengan transportasi laut, khususnya usaha keagenan kapal yang dilakukan oleh perusahaan pelayaran berbadan hukum berbentuk Perseroan Terbatas (PT).

Usaha keagenan saat ini sangat menjanjikan dengan adanya program pemerintah Tol Laut, karena dengan adanya tol laut yang tujuan utamanya memberi kelancaran rantai pasok distribusi barang yang dapat mengakibatkan turunnya harga barang di daerah yang jangkaunnya jauh, bahkan tujuan pemerintah untuk masalah harga ini bisa sama diseluruh tanah air.

Sebagai contoh bahwa di tahun 2107 dibuka trayek sejumlah 13 trayek dan tahun ini akan berkembang menjadi 15 Trayek tol laut, membuktikan bahwa harga di wilayah yang dulunya mahal sudah mulai turun sebagai contoh harga semen per Zak yang tadinya Rp 500.000,00 di Wamena turun menjadi Rp 300.000,00 per zak (kompas.com 14 Desember 2017)

Namun demikian dengan banyaknya trayek Tol laut akan memperbanyak aktivitas clearance Kapal di pelabuhan, yang berarti keamanan dan keselamatan pelayaran harus menjadi prioritas di kesyahbandara sebagaimana disampaikan menteri perhubungan bahwa perlu diperketat persyaratan pelayaran saat bertemu dengan Kepala BMKG Dwikorita Karnawati di Jakarta, Minggu (22/7/2018).

Untuk melayani tol laut yang semakin banyak trayeknya tersebut rantai pasok keseluruh pulau di Indonesia, membutuhkan jumlah kapal yang banyak, Pelabuhan juga harus ditingkatkan kwantitas dan kwalitasnya serta menyediakan infrastruktur dan juga tenaga kerjanya. Kondisi saat ini kebutuhan tersebut sudah diantisipasi oleh pemerintah dengan misalnya untuk kapal dilakukan pembuatan yang baru maupun membeli baik yang baru maupun pantas pakai, untuk pelabuhan sudah banyak dibuka, sedang infrastruktur lainnya tentunya akan menyesuaikan termasuk penyedaan tenaga kerja.

Sebagai Negara yang besar yang memiliki sebaran penduduk di banyak pulau dengan berbagai budaya dan suku serta kompleksnya permasalahan masing-masing pulau dengan berbagai kebutuhan baik primair (pokok) maupun kebutuhan sekundair, dengan berbagai latar belakang pendidikan demikian juga tingkatan kehidupan ekonomi di masing-masing wilayah (daerah) kondisi ini merupakan realita yang terjadi di Negara sebesar Indonesia dan intensitas perubahan pola hidup masyarakatnya sangat dinamis, sehingga pemeritah harus bisa meminimalisir permasalahan-permasalah yang ada agar dalam mempertahankan Negara Kesatuan Republik Indonesia ini bisa lestari.

Salah satu usaha untuk mengantisipasi hal tersebut perlu adanya pemerataan dan keadilan masyarakat, diseluruh wilayah tanah air, salah satu yang diupayakan pemerintah dengan membuat satu harga komoditas di seluruh Indonesia, walaupun kenyataannya satu harga ini dalam prakteknya belum bisa terlaksana, namun minimal turun dari harga sebelumnya, hal ini sangat dipengaruhi oleh kembalinya kapal yang memasok keseluruh wilayah tanah air ini belum membawa produk material maupun olahan dari wilayah yang sekarang ini dituju dengan kata lain 
suplay tidak diimbangi dengan demand atau kapal kembali dengan muatan yang sedikit bahkan kosong

Penulis tidak akan menyampaikan analisisnya tentang budaya, suplay/demand, komoditas maupun tingkatan kebutuhan ekonomi namun dalam menciptakan atau mendekatkan itu semua ada masalah transportasi laut yang menjadikan multiplayer pemenuhannya.

Transportasi laut dimaksud dalam tulisan ini berhubungan dengan kapal saat kapal ada di lautan, saat sebelum kapal datang, saat berada di Pelabuhan maupun saat meninggalkan pelabuhan dan juga saat kapal mengalami Doking di pelabuhan. Dari sekian banyak permasalahan tersebut masalah yang menjadi perhatian adalah sejauh mana kapal yang datang ke Pelabuhan tidak ada yang mengurusnya sehingga harus menunjuk perwakilan (agen) untuk mengurusinya sejak Kapal dari luar pelabuhan, masuk pelabuhan tambat di pelabuhan sampai kapal meninggalkan pelabuhan.

\section{KAJIAN LITERATUR}

Kegiatan ekonomi yang baik yang dapat menciptakan turunnya ekonomi biaya tinggi dan saat ini terjadi di Indonesia dilihat dari sektor kewilayahan, misalnya jawa dan Sumatra, Kalimantan apalagi kalau dibandingkan dengan Indonesia bagian timur akan sangat terasa perbedaannya.

Dari perbedaan harga inilah yang menjadikan kegiatan transportasi tol laut dibuka dengan konsekwensi tidak semua perusahaan pelayaran mempunyai cabang di semua pelabuhan. Dan untuk menyelesaikan masalah ini perlu dilakukan penunjukan perwakilan pengurusan Kapal, bongkar Muat oleh suatu instansi yang bernama usaha Keagenan.

Keberadaan Kapal yang ada di perairan (lautan) mempunyai tiga aktifitas Utama, yaitu saat kapal berada di laut lepas, saat kapal di Pelabuhan dan saat kapal masuk perbaikan (doking).

Sehubungan dengan masalah kapal berada di pelabuhan inilah identik dengan hal-hal yang berkaitan dengan keagenan karena Agen merupakan kegiatan mengurus kepentingan kapal perusahaan angkutan laut asing dan nasional selama berada di Indonesia, dan keagenan ini dilakukan oleh perusahaan nasional keagenan kapal atau perusahaan angkutan laut nasional (Martono dan Eko Budi Tjahyono 145)

Masalah Keagenan ini berdasarkan Undang-undang RI No 17 tahun 2008 pasal 11 ayat 5 bahwa angkutan laut asing yang melakukan kegiatan angkutan laut ke atau dari pelabuhan Indonesia yang terbuka untuk perdagangan luar negeri secara berkesinambungan dapat menunjuk perwakilannya di Indonesia. Juga di pasal (12) ketentuan lebih lanjut mengenahi kegiatan angkutan laut luar negeri, keagenan umum dan perwakilan perusahaan angkutan laut asing diatur dengan Peraturan Pemerintah.

Menurut Peraturan menteri perhubungan No: KM. 21 Tahun 2007 tentang Sistem dan Prosedur Pelayanan Kapal, Barang, dan Penumpang pada Pelabuhan Laut yang di selenggarakan oleh unit Pelaksana Teknis (UPT ) kantor Pelabuhan: Agen umum (General Agent) adalah perusahan angkutan laut nasional /penyelenggara kegiatan angkutan laut khusus yang di tunjuk oleh perusahaan 
angkutan laut asing di luar negeri untuk mengurus segala sesuatu yang berkaitan dengan kepentingan kapalnya (baik kapal milik, kapal charter maupun kapal yang dioperasikannya. Berdasarkan PM 74 tahun 2016 bahwa agen dibagi menjadi 2 yaitu:

1. Agen umum adalah perusahaan angkutan laut nasional atau perusahaan nasional yang khusus didirikan untuk melakukan usaha keagenan kapal yang ditunjuk oleh perusahaan angkutan laut asing untuk mengurus kepentingan kapalnya selama berada di Indonesia.

2. Sub Agen adalah perusahaan angkutan laut nasional atau perusahaan nasional yang khusus didirikan untuk melakukan usaha keagenan kapal di pelabuhan atau terminal khusus tertentu yang ditunjuk oleh agen umum.

Secara umum agen hanya dua saja namun dalam prakteknya masih dikanal istilah-istilah dalam keagenan seperti :

1. Booking Agent

Adalah perusahaan pelayaran atau forwarding yang ditunjuk untuk mengurusi muatan kapal dengan sistem liner

2. Special Agent (Agen Khusus)

Adalah perusahaan pelayaran yang ditunjuk untuk melayani kapal dengan sistem tramper pada saat Charter di suatu pelabuhan untuk kegiatan bongkarmuat

3. Port Agent

Adalah perusahaan pelayaran yang ditunjuk untuk melakukan tugas-tugas di suatu pelabuhan. Port Agent dapat menunjuk Sub Agent di pelabuhan lainnya untuk mewakilinya. Port Agent tetap bertanggung jawab terhadap principalnya.

4. Protectual Agent / Protecting Agent

Adalah agen yang ditunjuk oleh pencharter yang tercantum dalam Charter Party untuk mewakili kepentingannya.

5. Husbandary Agent

Adalah agen yang ditunjuk oleh principal untuk mewakili diluar kepentingan B/M, seperti mengurus ABK, Repair, Supplier dll.

6. Boarding Agent

Adalah petugas dari keagenan yang selalu berhubungan dengan pihak kapal. Biasanya Boarding Agent yang pertama naik ke kapal waktu kapal tiba dan terakhir meninggalkan kapal ketika kapal akan berangkat. (Dinas Luar Operasi)

7. Cargo Handling Agent

Adalah Perusahaan Bongkar Muat (PBM) yang ditunjuk untuk melayani kegiatan bongkar-muat di pelabuhan.

\section{Tugas Agen}

Secara umum tugas agen ada dua yaitu melaksanakan pelayanan kapal (labuh, pandu, tambat, bahan bakar, pelayanan air) (Abas Salim 114-115) yang diageni baik untuk fisik kapal apabila menghendaki perawatan, termasuk penyediaan onderdil (suku cadang kapal) yang dibutuhkan, juga pelayanan kepada anak Buah Kapal (ABK) dan melaksanakan kegiatan operasi keagenan seperti bongkar muat, trucking, mengatur muatan (stowage) serta dokumen muatan. 


\section{Penghasilan Agen Pelayaran}

Sebagai agen perusahaan pelayaran yang mewakili pemilik kapal secara penuh saat kapalnya menjelang masuk pelabuhan, berada di pelabuhan, dan meninggalkan pelabuhan Agen akan melayani seluruh kebutuhan/keperluan baik administrasi, fisik dan juga pembayaran-pembayaran yang dilakukan untuk memenuhi kebutuhan kapal saat berada di pelabuhan. Dengan melakukan aktifitas tersebut agen akan menerima penghasilan atas pelaksanaan kegiatan tersebut, yang berupa Komisi/Call Fee juga pendapatan usaha keagenan yang aktifitasnya diberikan kepada unit usaha lain seperti EMKL, sub Agency atau yang lain.

Kegiatan keagenan yang lain juga usaha yang berkaitan dengan pengurusan dokumen, baik dokumen kapal maupun dokumen perdagangan seperti: $B / L, S e a$ Waybills, Cargo Manifest, Freight manifest, Shipping notes, Mate's receipts, laporan bongkar muat kapal (Suyono 232)

\section{METODE}

Penulisan karya ilmiah ini adalah berdasarkan penelitian diskriptif yang berusaha mengemukakan dan memecahkan masalah dari kondisi lapangan saat ini, dengan mendasarkan data baik visual, literasi, yang ada yang dari hasil tersebut di analisis dan mengintepretasi, juga bisa bersifat kompratif dan korelatif (Cholid Narbuko dan Abu Achmadi)

Dalam penulisan karya ilmiah ini penulis menggunakan sumber-sumber yang berasal dari data skunder visual, literasi sehingga dalam mendiskripsikan tidak terlepas dari apa yang sekarang sedang berlangsung, memperkirakan kondisi yang akan datang dan membuat intepretasi sesuai dengan rumusan masalah yang menjadi bahasannya.

\section{HASIL DAN PEMBAHASAN}

Alktivitas tol laut mengakibatkan naiknya frekuensi kapal keluar masuk pelabuhan, hal ini mengakibatkan banyak perusahaan pelayaran tidak bisa mengurus kapalnya di semua pelabuhan yang disinggahi, dari sinilah peran keagenan kapal sangat dibutuhkan oleh semua Perusahaan Pelayaran untuk melayani kapalnya. Dalam pembahasan ini penulis membatasi hanya pada pengurusan keagenan sejak ditunjuk oleh principle (pemilik kapal) sebagai perwakilan (agen) untuk mengurusi kapal sejak Kapal dari luar pelabuhan, masuk pelabuhan tambat di pelabuhan dan kapal meninggalkan pelabuhan.

Aktivitas keagenan akan dimulai dari adanya perjanjian (letter of appointment atau Agreement) (LOA) yang didasari atas kesepakatan terhadap pekerjaan yang harus dilakukan dan berapa jumlah call fee atau komisi yang akan diberikan dalam mewakili berbagai urusan yang harus dilaksanakan.

Atas dasar perjanjian tersebut maka agen akan mengurus semua masalah yang akan terjadi saat kapal memasuki wilayah pelabuhan, masuk berada di pelabuhan dan meninggalkan pelabuhan.

\section{Saat Kapal akan Datang}

Setelah perjanjian yang juga berupa penunjukan keagenan, Persetujuan Keagenan Kapal Asing (PKKA) untuk kapal asing telah di dapatkan, maka 1 X 24 
jam kapal akan datang telah menerima pemberitahuan dari (principles/owner) bahwa kapalnya akan datang, pemberitahuan ini bisa melalui Fax/Cable Master dengan lampiran seperti Nama kapal, GT kapal, Manifes dan lainnya, dan apabila kapal yang diageni kapal asing perlu mengajukan Rencana Kedatangan Sarana Pengangkut (RKSP) melalui sistem Electronic Data Interchange (EDI) dengan memasukkan data Nama, Panjang, lebar, bendera kapal dan LOA dan sebagainya untuk mendapatkan bukti BC 01 bahwa kapal telah syah didaftarkan ke Bea dan Cukai.

Dengan dokumen tersebut maka agen segera mengambil langkah untuk melakukan Pengisian data Inaportnet (bagi pelabuhan yang telah menggunakan system ini) bagi yang belum maka akan menggunakan Pernyataan Umum Kapal (PUK) dengan Uang Pertanggung jawaban (UPER) untuk merubah status membuat warta kapal dengan berbagai lampiran diatas dan selanjutnya dikirim ke kantor Syahbandar dalam bentuk surat Pemberitahuan Kedatangan Kapal (PKK) dan Surat Persetujuan Kapal Masuk Pelabuhan (SPM), permohonan ini akan mendapatkan respon paling lama 5 Jam dari plafon waktu yang dicanangkan di Kantor Kesyahbandaran, namun dengan sistem First come First Sevice maka pelayanannya saat ini akan kurang dari 5 jam dari waktu yang di canangkan.

Dari hasil pengurusan diatas KSOP/BUP akan mengirim data Rencana Penambatan Kapal dan Rencana Operasi Kapal (RPK-RO) yang telah diverifikasi akan terbit Surat Perintah Kerja (SPK) Pandu dan satu Jam setelah SPK ini terbit maka terbit Surat Persetujuan Olah Gerak (SPOG) dan Kapal bisa dipandu dan bertambat di dermaga pelabuhan.

Dengan sistem Inaportnet ini pelayanan Kapal masuk Pelabuhan menjadi lancar dan ending dari input data inaportnet masuk akan keluat billing untuk biayabiaya seperti biaya Navigasi, biaya Labuh dan biaya rambu dan pembayaranya juga telah dilakukan dengan sistem online.

\section{Kapal Masuk Pelabuhan}

Saat kapal masuk di area pelabuhan dan kapal melakukan labuh jangkar agen juga akan melakukan boarding, biasanya menggunakan boat servece dengan petugas Karantina, Imigrasi, bea cukai, syahbandar untuk mengambil dokumen kapal, namun yang dilakukan/ kenyataannya dokumen diambil oleh Agen dan diserahkan/didistribusikan kepada:

1. Ka. Sie Kesyahbandaran

a. dokumen yang termuat dalam Memoradum

b. Crew List

c. Crew Personal Effect

d. Voyage Memo

e. Ammunition List atau Dangerous Cargo List

f. Store List dan Provision List

Dokumen-dokumen kapal dalam memorandum tersebut akan di cek masa berlakunya, dan apabila habis masa berlakunya akan diperpanjang dengan mekanisme sesuai dengan peraturan yang berlaku.

2. Dinas Kesehatan Pelabuhan

a. Crew List

b. Buku Kesehatan 
c. Ship Sanitasi Control, exemption certificate untuk kapal asing

d. Juga memeriksa kondisi fisik ruang perawatan, dapur, tempat sampah, air bersih, pengaman tikus dan setelah dinyatakan bebas dari penyakit maka petugas Kesehatan pelabuhan akan mengeluarkan certificate of pratique.

3. Imigrasi

Di instansi ini akan disampaikan dan diperiksa dokumen Pasport, buku Pelaut, crew list untuk di cap sebagai tanda diketahui kedatangannya dan kalau memang telah lengkap dan sesuai dengan yang dikehendaki maka Imigrasi akan mengeluarkan immigration clearance.

4. Bea dan Cukai

Bea cukai akan memeriksa kesesuaian dan kebenaran dokumen muatan dan muatan yang diangkut oleh kapal setelah pengecekan dokumen Memorandum Kapal dan lainnya, dengan certificate of pratique. dari kesehatan kapal dan immigration clearance. selanjutnya mohon diterbitkan Surat Persetujuan Berlayar(SPB) dari Kesyahbandaran untuk selanjutnya berangkat menuju pelabuhan yang akan disinggahi berikutnya.

\section{Pelayanan Kebutuhan kapal saat Di Pelabuhan}

Pelayanan kebutuhan kapal dibelabuhan bagi agen akan tergantung dari permintaan Nahkoda, yang informasinya diterima sebelum kapal sampai di pelabuhan antara lain :

a. Pengisian Bahan bakar

Pelayanan pengisian bahan bakar ini akan sangat tergantung dari kebutuhan kapal untuk perjalanan ke pelabuhan selanjutnya, sehingga nilai permintaannya akan selalu berbeda dari waktu ke waktu. Kalau ternyata membutuhkan maka untuk memenuhi permintaan ini Agen akan meminta Kepada Pertamina untuk mensuplay bahan bakar sesuai dengan kebutuhan kapalnya

b. Pengisian Air tawar

Pelayanan air tawar ini sama halnya dengan bahan bakar kalau kapal membutuhkan maka untuk memenuhinya agen akan meminta Kepada PDAM atau Pelindo untuk mensuplay air tawar sesuai dengan kebutuhan kapalnya

c. Perbekalan (Provision)

Pelayanan perbekalan ini akan disampaikan sebagaimana permintaan kapal kepada supplier (Ship chandler) untuk mengirimkan perbekalan Sayuran, buahbuahan dan berbagai kebutuhan lainnya juga spare part kapal, cat dll.

\section{Pelayanan Kebutuhan Awak kapal}

Pelayanan kebutuhan untuk awak kapal nahkoda juga membuat master dequest untuk kebutuhan Anak Buah Kapal (ABK)

a. Sign off dan Sign On Crew

Pengurusan ABK yang akan turun kapal karena perjanjian kerja lautnya telah habis atau sebaliknya yang akan bekerja di Kapal. Agen dalam kegiatan ini mempunyai tanggung jawab sampai pengurusan ke kantor Imigrasi mengenai ijin bagi kewarganegaraan asing yang akan masuk di Indonesia, dan juga mengurus masalah transportasi baik dari kapal ke Hotel atau ke bandara atau ke pelabuhan sesuai dengan kedatangan dan keberangkatan bagi ABK tersebut.

b. Mengurus ABK Sakit 
Apabila menemui ABK yang sakit maka Agen juga akan mengurusnya ke Rumah Sakut atau Poliklinik sampai ABK tersebut bisa bekerja kembali.

c. Pesiar (Auting) ABK

Dalam hal menemui kondisi ABK yang ingin Pesiar agen akan menguruskan transportasinya bahkan sampai mengurus ijin imigrasi (Shorepass) bagi ABK asing. Dalam hal pengurusan semua kebutuhan Kapal maupun ABK dan semua aktvitas kapal selesai maka agen akan membuat dokumen laporan pertanggung jawaban termasuk biaya karena telah selesainya pengurusan kapal yang di ageni.

\section{Keberangkatan Kapal}

Untuk mengurus keberangkatan Kapal ini apabila telah menggunakan Inaportnet akan berkaitan dengan Peraturan Direktur Jenderal Perhubungan Laut Nomor: HK.103/3/11/DJPL-15 tentang Tata Cara Pelayanan Kapal maupun barang maka dalam waktu paling lama 6 (enam) jam sebelum kapal keluar Agen mengajukan layanan kapal keluar, dengan input data di Inaportnet berupa Laporan Keberangkatan Kapal (LKK) dan Laporan Kedatangan dan Keberangkatan Kapal. (LK3), dan ke Syahbandar dalam bentuk SPB.

LKK yang telah di verifikasi oleh Penyelenggara Pelabuhan akan secara otomatis direspon oleh Sistem Informasi PNBP Online (SIMPONI) untuk penerbitan Kode Billing yang selanjutnya Agen melakukan pembayaran semua biaya Penerimaan Negara Bukan Pajak (PNBP) Labuh, Uang Rambu, Vessel Traffic System (VTS), Juga biaya Tambat, Pandu, Tunda, dan persewaan alat lainnya dari Kode Billing yang didapat, apabila telah dilunasi, secara otomatis LK3 dari agen sudah bisa dilakukan verifikasi dan masuk ke Syahbandar sehingga bisa melakukan penerbitan Surat Persetujuan Berlayar (SPB).

Selanjutnya dengan terbitnya SPB, maka paling lambat 1 jam setelah itu diterbitkan Surat Perintah Kerja (SPK) Pandu untuk kapal keluar dan paling lambat 1 (satu) jam setelah SPK pandu diterbitkan Surat Persetujuan Olah Gerak (SPOG) untuk kapal Keluar. Dan Agen akan mengurusnya dengan menyiapkan dokumen berikut ini :

1. Sailing Declaration dari karantina dan Quarantine Clearance

2. Cargo Manifest dan copy B.L.

3. Surat Persetujuan Berlayar (SPB)

4. Immigration Clearance

5. Custom Clearance.

Setelah dokumen keberangkatan dinyatakan lengkap maka agen dapat memberangkatkan kapal tersebut untuk melanjutkan perjalanan menuju pelabuhan singgah selanjutnya. Sampai disinilah pengurusan kapal yang menjadi tanggung jawab agen dengan tanpa mengurus barang baik yang di bogkar maupun yag dimuat, karena pengurusan Bongkar ini telah di tulis secara lengkap dalam edisi terbitan yang lain.

Dengan selesainya pengurusan keagenan kapal ini agen akan menghitung berapa biaya (dirbusement) yang dikeluarkan sebuhungan pengurusan kedatangan saat di pelabuhan sampai kapal meninggalkan pelabuhan. Total dari biaya yang dikeluarkan tersebut akan ditagihkan kepada Owner (principle) pemilik kapal dan 
ditambah dengan komisi yang telah di sepakati dalam perjanjian (Agreement) yang dibuat bersama.

\section{SIMPULAN}

Kegiatan pengurusan keagenan secara umum bisa dikatakan suatu instansi Pelayaran (pemilik Kapal) yang menyerahkan penanganan Kapalnya kepada Instansi lain yang sering disebut agen yang bisa mewakili untuk mengurusi kapalnya di Pelabuhan tertentu, baik dalam negeri maupun di luar negeri sehingga kapalnya bisa melakukan aktifitas dan terpenuhi segala sesuatu kebutuhan dan kewajiban yang harus di tanggungnya.

Kegiatan tersebut dilakukan mulai dari:

\section{Sebelum Kapal Datang.}

Agen akan melakukan segala sesuatu baik fisik maupun administrasi dengan menggunakan system innaportnet maupun tidak, hingga kapalnya bisa bersandar secara aman di Pelabuhan.

\section{Saat Kapal datang}

Agen akan melakukan bording dokumen Kapal bersama dengan instansi terkait atau melakukan sendiri yang selanjutnya mendistribusikan dokumen kepada instansi terkait hingga kegiatannya menghasilkan sesuati di semua instansi yang terkait.

3. Saat kapal berada di tambatan (dermaga) dengan aman dan melakukan aktifitas sampai selesai.

\section{Pelayanan Kebutuhan Kapal dan pelayanan kebutuhan crew kapal}

a. Pelayanan Kebutuhan Kapal

Didalam pelayanan kebutuhan kapal ini Agen akan memenuhi dan membiayai semua yang dibutuhkan seperti:

1) Kebutuhan Bahan Bakar

2) Kebutuhan Air Tawar

3) Perbekalan (Provision)

b. Kebutuhan Awak Kapal

Dalam pemenuhan kebutuhan ini awak kapal ini meliputi:

1) Sign off dan Sign On Crew

2) Perawatan di rumah sakit bila $\mathrm{ABK}$

3) Auting (Pesiar)

\section{Keberangkatan Kapal}

Dengan selesainya aktifitas kapal di pelabuhan maka agen akan mengurus semua yang berkaitan dengan kewajiban selama kapal masuk di Pelabuhan sampai keluar Pelabuhan baik administrasi (dokumen) maupun biaya yang harus dibayarkan dan melaporkan kegiatannya kepada owner dan pelabuhan yang akan disinggahi selanjutnya. 


\section{DAFTAR PUSTAKA}

Martono H.K dan Eko Budi Tjahyono, 2017, Transportasi Di Perairan berdasarkan UU No 17 Tahun 2008 RAJAWALI PERS, Cetakan ke 2 PT Raja Grafindo Persada Depok Jakarta

Salim Abas, 2008, Manajemen Transportasi Edisi 1 Jakarta Rajawali Pers PT Raja Grafindo Persada, Jakarta

Suyono, 2007, Shipping Pengangkutan Intermodal Ekspor Impor Melalui Laut Edisi ke Empat, Penerbit PPM

Peraturan Direktur Jenderal Perhubungan Laut Nomor: HK.103/3/11/DJPL-15 tentang Tata Cara Pelayanan Kapal maupun barang menggunaka Inaportnet 9 Maret 2017

Harga Komoditas Bahan Bangunan Turun, 14 Desember 2017. (kompas.com)

Dunia Maritim Informasi dan Edukasi tentang Dunia Maritim Minggu 26 Februari 2017

Kepala BMKG Dwikorita Karnawati di Jakarta Dunia Maritim , Minggu (22 Juli 2018).

Undang-undang RI No 17 tahun 2008 Tentang Pelayaran

Peraturan menteri perhubungan No: KM. 21 Tahun 2007 tentang Sistem dan Prosedur Pelayanan Kapal, Barang, dan Penumpang

PM 74 tahun 2016 Tentang Penyelenggaraan Dan Pengusahaan Angkutan Laut 